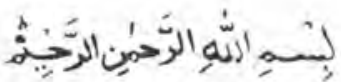

\section{MEMORANDUM ON RELIEF ASSISTANCE FOR \\ AFGHAN REFUGEES \\ IN PAKISTAN \\ 1992-93}

"STATES AND FRONTIER REGIONS DIVISION

GOVERNMENT OF PAKISTAN

ISLAMABAD

APRIL, 1992 


\title{
GOVERNMENT OF PAKISTAN
}

\section{STATES AND FRONTIER REGIONS DIVISION}

\author{
RELIEF ASSISTANCE FOR AFGHAN REFUGEES IN \\ PAKISTAN 1992-93 \\ (JULY 1992 - JUNE 1993)
}

The presence of Afghan refugees on Pakistan's soil, representing the World's single largest segment of displaced humanity and the need for their continued assistance till their voluntary return to their homeland in safety and with honour, are the facts which we have been narrating before the donor community year after year for over one decade. The World community has not only lent us a patient audience but have always responded positively in providing assistance for the sustenance of the Afghan refugees which Pakistan alone could hardly afford. We are grateful to the UN Agencies and the donor countries for the generosity exhibited by them towards the Afghan refugees and acknowledge with thanks the efforts made by the Aid-to-Pakistan Consortium for mobilizing moral and material support for them.

2. The year 1991 witnessed some very significant steps being taken towards a political settlement of the Afghan problem. Pakistan not only supported the UN initiatives in this regard but also took practical steps to mobilize support in favour of the Five Point Plan announced by the former UN Secretary General for the resolution of this problem. The new UN Secretary General immediately upon assumption of his assignment, has initiated some bold moves for resolving this knotty problem. The stoppage of military assistance to the parties to the Afghan conflict as a result of the negative symmetry signed between USA and the former USSR is also seen to be an important step towards the cessation of hostilities and the restoration of peace to Wartorn Afghanistan. All these efforts and initiatives, though positive enough to raise high expectations for the early political setllement of the Afghanistan's imbroglio are not likely to result in a large scale repatriation of Afghan refugees in the near future.

3. While large scale repatriation of Afghan refugees is not yet in sight, the voluntary repatriation, which had begun in July, 1990 as a 
result of the joint efforts of UNHCR, UNOCA and WFP is continuing at a slow pace. Till the middle of February, 1992 a total of 292,896 refugees had surrendered their ration pass books in return for the repatriation package of Rs. 3300 in cash and $300 \mathrm{k}$.g. of wheat per pass book. Despite the not so encouraging results of the project the Government of Pakistan strongly supports the continuation of this project to keep this option available to the refugees who may decide to return voluntarily.

4. To see the Afghan refugees returning home in large numbers the donor community has to wait for some time and till then the Afghan refugees in Pakistan need to be adequately looked after. With the process towards a political settlement on its track it has become more important than ever before that the international community sustains its efforts on the humanitarian front. Such assistance will not only help alleviate the sufferings of the Afghan refugees but will also reinforce the peace process. It is all the more important that the donor community refines its perception regarding the requirements of the Afghan refugees' humanitarian assistance and commits adequate resources for their relief programme so desparately needed for their sustained maintenance.

5. In keeping with the factual position described above the following topics have been dealt with in this document:-
A. Food Assistance.
B. UNHCR's Assistance.
C. Replacement of Transport Fleet.
D. Economic Recovery and Rehabilitation Programme.
E. Extension of Income Generating Project for Refugee Areas (IGPRA).
F. Outflow of essential commodities from Pakistan to Afghanistan.

\section{A. FOOD ASSISTANCE}

6. The Joint WFP/UNHCR's Food Assessment Mission that visited Pakistan in May, 1990, had recommended the following 
quantities of food assistance for 1991 on reduced ration scale for a registered population of 3.35 million:-

$\begin{array}{lr}\text { Wheat. } & 482,400 \text { M.T. } \\ \text { Edible Oil. } & 24,100 \text { M.T. } \\ \text { DSM. } & 1,200 \text { M.T. }\end{array}$

7. The donors delivered a quantity of 400,540 M.T. of wheat by the end of 1991. Against this the total quantity of wheat distributed during 1991 was 361,700 M.T. The low distribution of wheat was mainly because of the delay in the delivery of pledges and the inability of the Food Departments of NWFP and Balochistan to release wheat to Afghan refugees on replenishment basis due to their depleted stocks. Their stocks in the first eight months could not even meet the domestic requirements.

8. As regards edible oil the quantities delivered during the year were far short of the assessed requirement. Against the estimated requirement of $24,100 \mathrm{M}$.T the commitments made by the donors were 13,449 M.T. The actual deliveries were even far less i.e. only 7,929 M.T. As a result, there was a shortfall of 16,171 M.T.

9. As regards other items the pledged quantity of 1,200 M.T. of DSM could not be delivered by the donors during 1991. It has been delivered in January, 1992. The Chinese Government, however, provided their pledge of 40 M.T. of tea.

10. Although the Joint Food Assessment Mission recommended deletion of sugar and tea and the general distribution of D.S.M. from the food basket and reduced scales of ration of wheat and edible oil by 20 per cent and 33 per cent respectively, yet Government of Pakistan has been stressing at every forum that all these items of food basket should be provided, because their exclusion from the food basket results in pressure on our market in the form of increased demand and soaring prices. Since these items are mostly on our import list they inflate our import bill too. We would strongly plead the reinclusion of these items viz. the full requirement of DSM, Sugar and Tea in the food basket of the Afghan refugees. 
11. We have been highlighting at almost all the United Nations fora that the cumulative shortfalls of wheat, which according to the report prepared by the World Food Programme work out to 710,600 M.T. should be provided by the donor community to Pakistan as Pakistan has suffered this heavy additional burden by releasing wheat to Afghan refugees to meet shortfalls in donations. It may be recalled that Government of Pakistan is already meeting the inland transportation, storage and handling (ITSH) costs of all the relief goods received for Afghan refugees ever since the inception of the relief programme in 1979-80. The annual expenditure on this account is now around \$ 37 million.

12. For the year 1992 Government of Pakistan has worked out the feeding requirement of a case-load of 2.8 million refugees in the light of the discussions held with the Joint WFP/UNHCR Food Assessment Mission on 4th March, 1992 in Islamabad. This figure has been arrived at after deducting the figure of voluntary repatriation and adopting the revised figure of refugee population in Balochistan of 450,000 determined through mutual consultation on the basis of a sample survey of some refugee camps. The Mission recommended to provide only two commodities i.e. whe at and edib!e oil on the scale of $400 \mathrm{grams}$ and 20) gams respectively per head per day. The requirements of the other items have been worked out at full scale of ration. The requirements are estimated to be as follows:

\begin{tabular}{|c|c|c|}
\hline Food Item & Quantity & Cost in US \$ \\
\hline Wheat. & 414,000 M.T. & $67,068,000$ \\
\hline Edible Oil & $21.000 \mathrm{M}, \mathrm{T}$ & $23,625,000$ \\
\hline DSM. & 30,240 М.T. & $56,700.000$ \\
\hline Sugar: & 20,150 M.T. & $7,560,000$ \\
\hline Tea. & $1,512 \mathrm{M} . \mathrm{T}$ & $4,725,000$ \\
\hline Dates. & 10,000 М.T. & $12,500,000$ \\
\hline \multirow{3}{*}{$\begin{array}{l}\text { Inland Transportation, } \\
\text { ling (ITSH) costs, }\end{array}$} & Tola1: & $172,178,000$ \\
\hline & , Storage and Hand- & $37,000,000$ \\
\hline & Grand Total: & $209,178,000$ \\
\hline
\end{tabular}




\section{B. UNHCR'S ASSISTANCE}

13. The cash assistance from UNHCR under the General Programme has been subjected to drastic cuts since 1987 as indicated below:

\begin{tabular}{cc}
\hline Year & UNHCR's cash assistance \\
\hline & (US S million) \\
1987 & 47.300 \\
1988 & 41.340 \\
1989 & 36.020 \\
1990 & 30.930 \\
1991 & 30.555 \\
1992 (estimated) & 26.494 \\
\hline
\end{tabular}

14. The declining availability of resources has seriously affected the relief assistance programme necessitating the deletion of the livestock care from the programme and closure of some facilities in the Health, Education and Water Supply Sectors. In addition, the delayed releases of instalments during the year 1991 also adversely affected the implementation of the programme.

15. In the begining of 1991, Government of Pakistan agreed with the UNHCR to effect retrenchment to the extent of $30 \%$ in the Afghan Refugee Organisations. Further retrenchment to the extent of $30 \%$ of the 1990 strength ( $50 \%$ of the existing strength) is on the anvil. The compensation package required to be paid to the employees retrenched earlier and those to be retrenched now is estimated to be US\$ 5 million. Since the Government of Pakistan has already had to face very serious problem as a result of the earlier staff retrenchment, as the employees who lost their jobs are agitating the issue of loss of their jobs at every forum, it genuinely expects the donors to donate funds for the compensation package to relieve it of the financial liability on this account. Simultaneously we would request the UNHCR not to effect any further reduction in the logistic support budget as it will have 
detrimental effects on the Refugee Administration. Any further reduction of staff may be pended till substantial repatriation of Afghan refugees.

16. For the year 1992 our requirement of kerosene oil is estimated to be about 80 million litres. The donation of 20 million litres of kerosene oil. which was announced by Saudi Arabia in 1990, has been received in 1992. Presuming that the UNHCR would provide funds for the purchase of 13 million litres as before the total likely availability of kerosene oil for 1992 is expected to be only 33 million litres leaving a shortfall of 47 million litres costing about US $\$ 10$ million.

17. The total requirement of WFP, and UNHCR's Programme for the year 1992 would thus be US \$250.672 million as follows:-

(a) WFP's Commodity assistance (in- \$ 209.178 million cluding ITSH costs of \$37 million.)

(b) UNHCR's Assistance.

\$ 41.494 million

Total:

$\$ 250.672$ million

C. REPLACEMENT/REQUIREMENT OF TRANSPORT FLEET

18. For the past three yeurs the Government of Pakistan has been inviting the attention of the Aid-to-Pakistan Consortium to the partial replacement of the ageing transport fleet engaged in carrying relief items to Afghan refugee camps. Most of these vehicles are of the early Eighties' vintage. After continuously plying in the rough and rugged terrain for about a decade these are in a deplorable state from functional and operational point of view. Even when handed over to us some of these were second hand vehicles. Thus not only age is fast taking these to a state of virtual obsolescence but also manufacturing of a majority of these vehicles has ceased. It is thus impossible to get their spare parts. Needless to say that the Government of Pakistan is operating this fleet. which has outlived its useful life long ago, at a prohibitive cost. Their replacement is now an essential pre-requisite for 
the uninterrupted flow of relief goods to camps. During 1990 we could get only 29 vehicles ( 25 donated by South Korea and 4 purchased from a small left over portion of a Japanese grant). In January this year (1992) 100 trucks, one mobile workshop truck and two towing trucks donated by the Japanese Government were handed over to us by the World Food Programme on lease for the transportation of relief commodities for humanitarian assistance of Afghan refugees inside Pakistan. These 100 trucks are actually meant for the repatriation programme and according to the Lease Agreement these are to be made available to WFP when required by them for the repatriation programme. Since the provision of these 100 vehicles by WFP on lease is a temporary relief, our requirements of vehicles for partial replacement/augmentation of the existing fleet remains the same as was presented before this forum last year viz:

(a) Trucks.

(b) Oil/Water tankers.

(c) Utility vehicles.

(d) Cars.

(e) Motor cycles.

\section{ECONOMIC RECOVERY AND REHABILITATION}

19. In the 1988 Aid-to-Pakistan Consortium meeting, the Government of Pakistan presented the proposal of restoration of the substantial ecological damage caused to Pakistan by the protracted presence of Afghan refugees in the NWFP, Balochistan and Punjab. In the 1989 meeting complete detaiis were once again presented before the Consortium meeting with the total estimated cost of the projects at US $\$ 423.30$ million. UNDP picked up the idea and fielded a survey team during 1990 to assess the extent of the damage caused and the cost of its repair. The survey team after holding a series of meetings with SAFRON as well as wtih the concerned line departments in the provinces and extensive visits to the affected areas submitted a detailed report in September, 1990. 
20. The team in its report has stated that the forests, rangelands, roads and canals have reached a critical stage in a long process of deterioration which was further speeded up by the presence of Afghan refugees and that in some cases the degradation may even be irreversible. It further recommended that determined action is required to halt and, if possible, reverse the deterioration. According to the team's recommendations certain projects may have to be taken up after the refugees' departure but there are many projects which can be completed even when the refugees remain in Pakistan. These include activities relating to repair and rehabilitation of roads, canals and water supplies. The problems in this sphere can be defined, the solutions arc clear and the line departments are used to carrying out such works. The team has placed the projects in three categories i.e. high priority, medium priority and low priority. For high priority projects the team has suggested a total cost of US \$102 million to be disbursed over five years. Summaries of these projects as prepared by the team were circulated last year. These are once again annexed ( $A$ to $G$ ) for the use of potential donors.

21. The Government of Pakistan has accepted the report with some modifications and has informed the UNDP accordingly. It is expected that the UNDP will soon be in a position to present the final report to the donors for appropriate financial assistance for the implementation of the proposed projects.

22. We are looking forward to prompt and generous donors' response for the implementation of the recovery and rehabilitation programme in accordance with the recommendations of the UNDP's Survey Mission. Although the damage caused to the environment is enormous and the cost of its repair would be colossal at least a beginning could be made to repair some of the damage in the light of the expert study conducted under the aegis of the UNDP.

\section{E. INCOME GENERATING PROJECT FOR REFUGEE AREAS}

23. In order to provide job opportunities to Afglian refugees and to restore some of the damage caused by the presence of these refugees in 
Pakistan, a project under the caption "Income Generating Project for Refugee Areas" was initiated in 1984. Its first phase was completed in September, 1987 at a cost of Rs. 316.620 million. Its second phase. involving an outlay of Rs. 900 million, was started from October, 1987 and completed by December, 1990 leaving some works in progress which were also completed by June, 1991. Due to continued presence of Afghan refugees on the soil of Pakistan, the Aid to Pakistan Consortium in its meeting held on 20-21 April, 1989 in Paris gave a positive indication to keep the project alive. Consequently, it was hoped that third phase of the project which was estimated to cost about $\$ 28$ million would start from January, 1991. But, the third phase is not yet off the ground despite the fact that essential requisite action has been completed by the Government of Pakistan. Initially, it was planned to be launched in July, 1991, which was subsequently postponed till January, 1992. The activities of the field offices particularly those pertaining to Forestry Department have, however, been kept alive by providing bridging funds tagged with limited targets for forestry sub-projects for the duration of January--December, 1991 called "Bridging Period".

24. PC-Is of some 68 projects proposed to be undertake ${ }_{u}$ during third phase have been completed, successful negotiations have been held with the World Bank and certain donors including Germany, Netherlands, EEC and Sweden have indicated their pledges for the implementation of the third phase. But the funds have not so far been remitted to the Trust Fund, established by the World Bank for the purpose and the legal formalitics are pending finalisation. The result is that the duration of the "Bridging Period" which was first extended from July, 1991 to December, 1991 is being further stretched calusing difficulties and bottlenecks for the line departments. The physical targets which were actually planned for Phase-III (January - June. 1992) have now fallen into the lap of the Bridging Period for which additional funds are required. There is a need for the speedy finalisation of the legal formalities by the UNHCR, World Bank and the donors so that necessary funds i.e. US $\$ 26$ million are provided and the third phase of the IGPRA is launched without any further delay. 


\section{OUTFLOW OF ESSENTIAL COMMODITIES FROM PAKISTAN TO AFGHANISTAN}

25. The prevalent and potential shortages of essential commodities in Afghanistan is currently causing a visible drain on the markets in Pakistan. Gcographical contiguity and long porous border provide ideal condition for an easy outflow of Pakistani goods into Afghanistan. Items like wheat, edible oil, sugar, tea, fuel, fertilizers, construction material etc. most of which figure on Pakistan's own import list are being sucked into the depleted markets of Afghanistan calusing shortages and price spirals in the domestic markets of Pakistan. Pakistan has thus come under the pressure of reduced assistance for Afghan Refugees on the one hand and the outflow of its own scarce resources on the other. With the political settlement of the Afghan problem. now in sight, and the accompanying need of the reconstruction of Afghanistan and the rehabilitation of the returning refugees coupled with the emergenee of the newly independent Central Asian Republics the flow of food commodities and other goods from Pakistan is likely to increase manifold. This phenomenon needs urgent donors' attention to release the pressure on Pakistan to some extent. The positioning of goods inside Afghanistan, earlier visualized by the United Nations, apart from lessening the drain on Pakistan's economy, will be a welcome and positive step in the direction of rehabilitation and reconstruction of Aghanistan and will facilitate the re-settlement of the returning Afghan relugees.

26. A brief summary of the Afghan Refugees Relief Assistance lor 1992 described in the preceding paragraphs is as follows:

(i) US \$250.672 million for the UNHCR's/WFP's relief assistance for 1992.

(b) US \$26 million for Phase-III of Income Generating Project for Refugee Areas.

(c) 377 heavy trucks, 130 oil/water tankers, 136 utility vehicles. 10 cars and 150 motorcycles.

(d) Donations both in cash and kind to offset the liability in respect of $710,600 \mathrm{M}$.T. of wheat released by Government of Pakistan out of its own stocks for Afghan refugees on replenishment basis. The cost comes to US $\$ 115$ million. 
Annexure-A

SUMMARY OF THE HIGH PRIORITY PROGRAMME: BY SECTOR AND PROVINCE

\begin{tabular}{|c|c|c|c|c|c|c|}
\hline \multirow[b]{2}{*}{ Province } & \multicolumn{4}{|c|}{ Sector } & \multicolumn{2}{|c|}{ Tolal } \\
\hline & $\begin{array}{l}\text { Roads } \\
\text { M Rs. }\end{array}$ & $\begin{array}{l}\text { Irrigation } \\
\text { M Rs. }\end{array}$ & $\begin{array}{c}\text { PH } \\
\text { Engincering } \\
\text { M Rs. }\end{array}$ & $\begin{array}{c}\text { Vegetative } \\
\text { Rehabilitation } \\
\text { M Rs. }\end{array}$ & M Rs. & US S M \\
\hline NWFP & 719.000 & 285.560 & 123,050 & 332.995 & 1460.605 & 69.55 \\
\hline Baluchistan & 165.000 & 56.800 & 103,840 & 94.376 & 420.016 & 20.00 \\
\hline Punjab & 79.000 & 93.930 & 92.300 & 11.679 & 276.909 & 13.19 \\
\hline \multirow[t]{2}{*}{ TOTAL: Programme } & 963.000 & 436.290 & 319.190 & 439.050 & 2157.530 & 102.74 \\
\hline & $\begin{array}{r}\text { USS M } \\
45.86\end{array}$ & $\begin{array}{r}\text { USS M } \\
20.78\end{array}$ & $\begin{array}{r}\text { US\$ } M \\
15.20\end{array}$ & $\begin{array}{r}\text { USS M } \\
20.91\end{array}$ & $\begin{array}{r}\text { USS M } \\
102.74\end{array}$ & \\
\hline
\end{tabular}


Annexure-B

SUMMARY OF THE MEDIUM AND LOW PRIORITY PROGRAMME: BY SECTOR AND PROVINCE

\begin{tabular}{|c|c|c|c|c|c|c|c|c|}
\hline \multirow{4}{*}{ Province } & \multicolumn{6}{|c|}{ Sector } & \multicolumn{2}{|c|}{ Total } \\
\hline & \multirow{3}{*}{$\begin{array}{l}\text { Roads } \\
\text { M Rs. }\end{array}$} & \multirow{3}{*}{$\begin{array}{l}\text { Irrigation } \\
\text { M Rs. }\end{array}$} & \multirow{3}{*}{$\begin{array}{l}\text { PH } \\
\text { Engineering } \\
\text { M Rs. }\end{array}$} & \multirow{3}{*}{\multicolumn{3}{|c|}{\begin{tabular}{lcc}
\multicolumn{3}{c}{ Vegetative Rehabilitation } \\
Med. & Low & Sub-Total \\
Priority & Priority & \\
M Rs. & M Rs. & M Rs.
\end{tabular}}} & \multirow[b]{3}{*}{ M Rs. } & \multirow[b]{3}{*}{ US S M } \\
\hline & & & & & & & & \\
\hline & & & & & & & & \\
\hline \multirow[t]{2}{*}{ NWFP } & 961.000 & 0.000 & 0.000 & 148.176 & 22.975 & 171.151 & 1132.151 & 53.91 \\
\hline & & & & & & & 0.000 & 0.000 \\
\hline \multirow[t]{2}{*}{ Baluchistan } & 547.000 & 0.000 & 0.000 & 127.195 & 138.216 & 265.411 & 812.411 & 38.69 \\
\hline & & & & & & & & 0.00 \\
\hline Punjab & 192.000 & 0.000 & 0.000 & 0.000 & 80.786 & 80.786 & 272.786 & 12.99 \\
\hline \multirow[t]{3}{*}{ TOTAL: Programme } & 1700.000 & 0.000 & 0.000 & 275.371 & 241.977 & 517.348 & 2217.348 & 105.59 \\
\hline & US\$ M & USS M & USS M & & & USS M & USS $M$ & \\
\hline & 80.95 & 0.000 & 0.000 & & & 26.64 & 105.59 & \\
\hline
\end{tabular}


Annexure-C

SUMMARY OF THE OVERALL PROGRAMME PROPOSED: BY SECTOR AND PROVINCE AND WITHOUT REGARD TO PRIORITIES FOR ACTION

\begin{tabular}{|c|c|c|c|c|c|c|}
\hline \multirow[b]{2}{*}{ Province } & \multirow[b]{2}{*}{$\begin{array}{l}\text { Roads } \\
\text { M Rs }\end{array}$} & \multicolumn{2}{|c|}{ Sector } & \multirow[b]{2}{*}{$\begin{array}{l}\text { Vegetalive } \\
\text { Rehubilitation } \\
\text { M Rs. }\end{array}$} & \multicolumn{2}{|c|}{ Total } \\
\hline & & $\begin{array}{l}\text { Irrigation } \\
\text { M Rs. }\end{array}$ & $\begin{array}{l}\text { PH } \\
\text { Engincering } \\
\text { M Rs. }\end{array}$ & & M Rs. & US SM M \\
\hline NWFP & 1680.000 & 285.560 & 123.050 & 504.146 & 2592.756 & 123.46 \\
\hline Baluchistan & 712.000 & 56.800 & 103.840 & 359.787 & 1232.427 & 58.69 \\
\hline Punjab & 271.000 & 93.930 & 92.300 & 92.465 & 549.695 & 26.18 \\
\hline \multirow[t]{2}{*}{ TOTAL: Programme } & 2663.000 & 436.290 & 319.190 & 956.398 & 4374.878 & 208.33 \\
\hline & $\begin{array}{r}\text { USS M } \\
126.81\end{array}$ & $\begin{array}{r}\text { USS M } \\
20.78\end{array}$ & $\begin{array}{r}\text { USS M } \\
15.20\end{array}$ & $\begin{array}{r}\text { USS M } \\
45.54\end{array}$ & $\begin{array}{r}\text { USS M } \\
208.33\end{array}$ & \\
\hline
\end{tabular}


Annexure-D

SUMMARY OF THE ROADS SECTORAL SUB-PROGRAMME

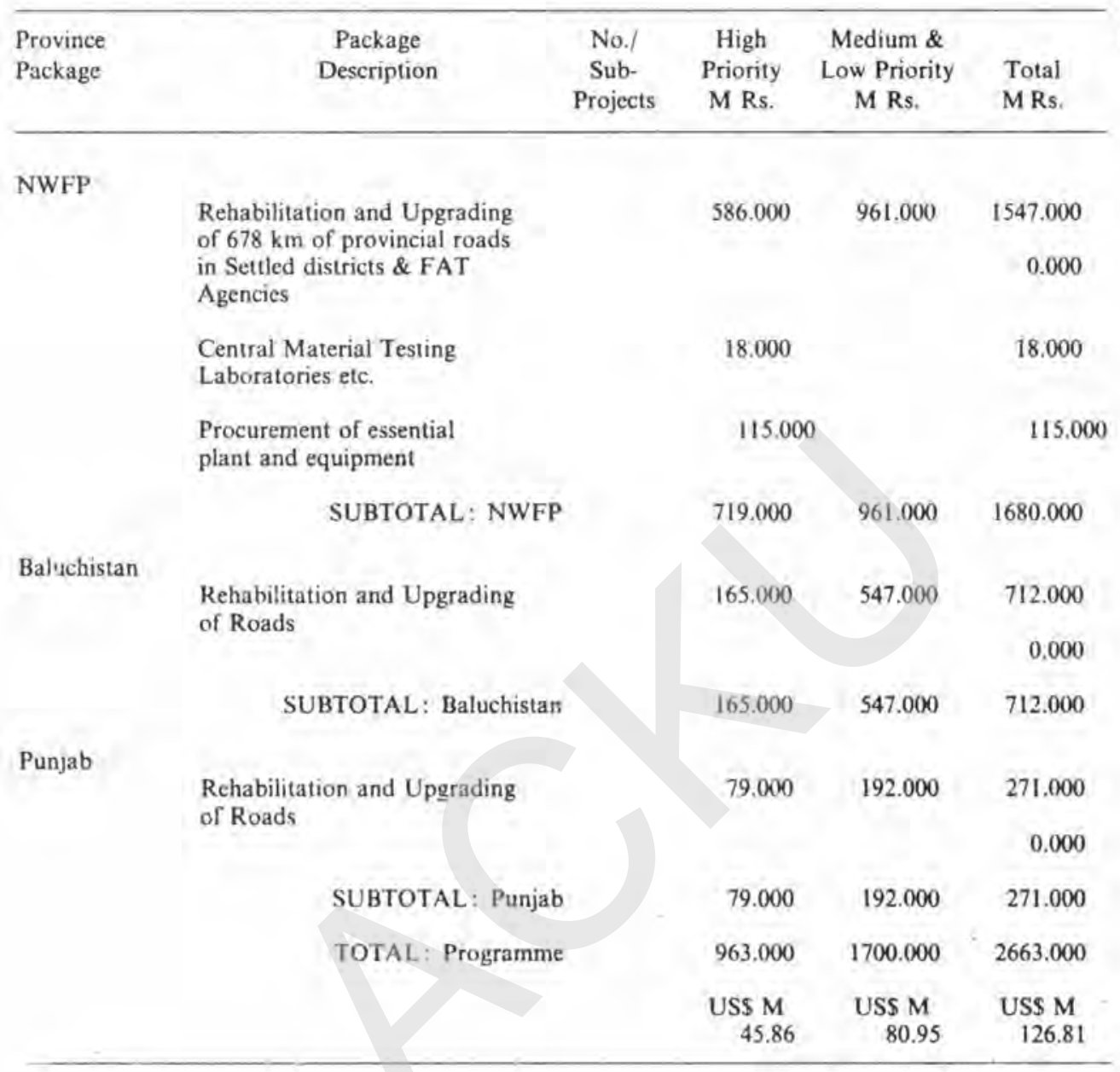


SUMMARY OF THE IRRIGATION SECTORAL SUB-PROGRAMME

\begin{tabular}{|c|c|c|c|c|c|c|}
\hline $\begin{array}{l}\text { Province } \\
\text { Package }\end{array}$ & $\begin{array}{c}\text { Package } \\
\text { Description }\end{array}$ & $\begin{array}{l}\text { No./ } \\
\text { Sub- } \\
\text { Projects }\end{array}$ & $\begin{array}{l}\text { High } \\
\text { Priority } \\
\text { M Rs. }\end{array}$ & $\begin{array}{l}\text { Medium } \\
\text { Priority } \\
\text { M Rs. }\end{array}$ & $\begin{array}{l}\text { Low } \\
\text { Priority } \\
\text { M Rs. }\end{array}$ & $\begin{array}{l}\text { Total } \\
\text { M Rs. }\end{array}$ \\
\hline \multirow[t]{4}{*}{ NWFP } & Rehabilitation of Canal Lining & 4 & 33,390 & & & 33.390 \\
\hline & Patrol Road Rehabilitation & 6 & 80.320 & & & 80.320 \\
\hline & Joint Rehabilitation Schemes & 5 & 171.850 & & & 171.850 \\
\hline & SUBTOTAL: NWFP & & 285.560 & 0.000 & 0.000 & 285.560 \\
\hline \multirow[t]{5}{*}{ Báluchistan } & $\begin{array}{l}\text { Rehabilitation of existing } \\
\text { Karez \& other small irrigation } \\
\text { schemes }\end{array}$ & 16 & 35.800 & & & 35.800 \\
\hline & $\begin{array}{r}\text { Construction of Delayed } \\
\text { Action Dams for Aquifer } \\
\text { Recharge }\end{array}$ & 4 & 17.700 & & & 17.700 \\
\hline & Tube Well Development & 1 & 2.500 & & & 2.500 \\
\hline & $\begin{array}{r}\text { Rehabilitation of Spate } \\
\text { Irrigation Schemes }\end{array}$ & 1 & 0.800 & & & 0.800 \\
\hline & SUBTOTAL: Baluchistan & & 56.800 & 0.000 & 0.000 & 56.800 \\
\hline \multirow[t]{5}{*}{ Punjab } & Rehabilitation of Canal Lining & 1 & 67.290 & & & 67.290 \\
\hline & $\begin{array}{l}\text { Joint rehabilitation of Canal } \\
\text { Lining and Patrol Roads }\end{array}$ & 1 & 26.640 & & & 26.640 \\
\hline & SUBTOTAL: Punjab & & 93.930 & 0,000 & 0.000 & 93.930 \\
\hline & TOTAL: Programme & & 436.290 & 0.000 & 0.000 & 436.290 \\
\hline & & & $\begin{array}{l}\text { USS M } \\
20.78\end{array}$ & $\begin{array}{l}\text { USS M } \\
0.00\end{array}$ & $\begin{array}{l}\text { US\$ M } \\
0.00\end{array}$ & $\begin{array}{l}\text { USS M } \\
20.78\end{array}$ \\
\hline
\end{tabular}


Annexure-F

SUMMARY OF THE PUBLIC HEALTH ENGINEERING SECTORAL SUB-PROGRAMME

\begin{tabular}{|c|c|c|c|c|c|c|}
\hline $\begin{array}{l}\text { Province } \\
\text { Package }\end{array}$ & $\begin{array}{c}\text { Package } \\
\text { Description }\end{array}$ & $\begin{array}{c}\text { No,/ } \\
\text { Sub- } \\
\text { Projects }\end{array}$ & $\begin{array}{l}\text { Iligh } \\
\text { Priority } \\
\text { M Rs. }\end{array}$ & $\begin{array}{l}\text { Medium } \\
\text { Priority } \\
\text { M Rs. }\end{array}$ & $\begin{array}{l}\text { Low } \\
\text { Priority } \\
\text { M Rs. }\end{array}$ & $\begin{array}{l}\text { Total } \\
\text { M Rs. }\end{array}$ \\
\hline \multirow[t]{2}{*}{ NWFP } & $\begin{array}{l}\text { Tube Well boring \& provision } \\
\text { of reticulation infrastructure }\end{array}$ & 36 & 123.050 & & & $\begin{array}{r}123.050 \\
0.000\end{array}$ \\
\hline & SUBTOTAL: NWFP & & 123,050 & 0.000 & 0.000 & 123.050 \\
\hline Baluchistan & $\begin{array}{l}\text { Tube Well boring \& provision of } \\
\text { reticulation infrastructure }\end{array}$ & 16 & 103.840 & & & $\begin{array}{r}103.840 \\
0.000\end{array}$ \\
\hline & SUBTOTAL: Baluchistan & & 103.840 & 0.000 & 0.000 & 103.840 \\
\hline \multirow[t]{4}{*}{ Punjab } & $\begin{array}{l}\text { Tube Well boring \& provision of } \\
\text { reticulation infrastructure }\end{array}$ & 11 & 92.300 & & & $\begin{array}{r}92.300 \\
0.000\end{array}$ \\
\hline & SUBTOTAL: Punjab & & 92.300 & 0.000 & 0.000 & 92.300 \\
\hline & TOTAL: Programme & & 319.190 & 0.000 & 0.000 & 319.190 \\
\hline & & & $\begin{array}{l}\text { USS M } \\
15.20\end{array}$ & $\begin{array}{c}\text { US\$ } \mathrm{M} \\
0.00\end{array}$ & $\begin{array}{l}\text { USS M } \\
0.00\end{array}$ & $\begin{array}{l}\text { US\$ M } \\
15.20\end{array}$ \\
\hline
\end{tabular}


Annexure-G

\section{SUMMARY OF THE FORESTRY AND VEGETATION REHABILITATION SECTORAL SUB-PROGRAMME}

\begin{tabular}{|c|c|c|c|c|c|c|}
\hline $\begin{array}{l}\text { Province } \\
\text { Package }\end{array}$ & $\begin{array}{c}\text { Package } \\
\text { Description }\end{array}$ & $\begin{array}{l}\text { No.l } \\
\text { Sub- } \\
\text { Projects }\end{array}$ & $\begin{array}{l}\text { High } \\
\text { Priority } \\
\text { M Rs. }\end{array}$ & $\begin{array}{l}\text { Medium } \\
\text { Priority } \\
\text { M Rs. }\end{array}$ & $\begin{array}{l}\text { Low } \\
\text { Priority } \\
\text { M Rs. }\end{array}$ & $\begin{array}{l}\text { Total } \\
\text { M Rs. }\end{array}$ \\
\hline \multicolumn{7}{|l|}{ NWFP } \\
\hline & $\begin{array}{l}\text { 1. Afforestation \& Soil cons. } \\
\text { Degraded Upland W'Sheds, } \\
\text { Hazara Division }\end{array}$ & 6 & & 148.176 & & 148.176 \\
\hline & $\begin{array}{l}\text { L. Afforestation \& soil Cons, } \\
\text { Degraded Upland W'Sheds, } \\
\text { Malakand Division }\end{array}$ & 5 & 106.716 & & 22.975 & 129.691 \\
\hline & $\begin{array}{l}\text { 3. Planting of Lowland and sites I } \\
\text { Region (modified vegetative } \\
\text { re-establishment programme) }\end{array}$ & 5 & 105.000 & & & 105 \\
\hline & $\begin{array}{l}\text { 4. Mazri Palm Development I } \\
\text { S. Region }\end{array}$ & 4 & 84.000 & & & 84 \\
\hline & $\begin{array}{l}\text { 5. Afforestation \& Soil Cons. } \\
\text { Degraded Hillsides in S. Region }\end{array}$ & 1 & 37.279 & & & 37.279 \\
\hline & SUBTOTAL: NWFP & & 332,995 & 148.176 & 22.975 & 504,146 \\
\hline \multicolumn{7}{|c|}{ Baluchistan } \\
\hline & $\begin{array}{l}\text { I. Soil Conservation Works I } \\
\text { Pishin District }\end{array}$ & 4 & 94.376 & & & 94.376 \\
\hline & $\begin{array}{l}\text { 2. soil Conservation Works I } \\
\text { Quetta District }\end{array}$ & 1 & & & 69.108 & 69.108 \\
\hline & $\begin{array}{l}\text { 3. soil Conservation Works } 1 \\
\text { Chaghi District }\end{array}$ & 1 & & & 69.108 & 69.108 \\
\hline & $\begin{array}{l}\text { 4. Soil Conservation Works I Ziarat, } \\
\text { Killa Saifullah, Loralai \& Zhob } \\
\text { Districts }\end{array}$ & 7 & & 127.195 & & 127.195 \\
\hline & SUBTOTAL: Baluchistan & & 94,376 & 127.195 & 138,216 & 359.787 \\
\hline \multicolumn{7}{|l|}{ Punjab } \\
\hline & $\begin{array}{l}\text { 1. Rehabilitation of 1rrigated } \\
\text { Plantation Systems }\end{array}$ & 1 & & & 64.200 & 64.200 \\
\hline & 2. Roadside Planting & 1 & & & 16.586 & 16.586 \\
\hline & $\begin{array}{l}\text { 3. Seedling Production for } \\
\text { Distribution to Farmers }\end{array}$ & 1 & 11.679 & & & 11.679 \\
\hline & SUBTOTAL: Punjab & & 11.679 & & 80.786 & 92.465 \\
\hline & TOTAL: Programme & & 439.05 & 275.371 & 241.977 & 956,398 \\
\hline & & & $\begin{array}{l}\text { US\$ M } \\
20.91\end{array}$ & $\begin{array}{l}\text { US\$ M } \\
13.11\end{array}$ & $\begin{array}{l}\text { US\$ M } \\
11.52\end{array}$ & $\begin{array}{l}\text { US\$ M } \\
45.54\end{array}$ \\
\hline
\end{tabular}

